\title{
Tribology of Natural Fibers Composite Materials: An Overview
}

\author{
Marko Milosevic $^{1, *(\mathbb{D})}$, Petr Valášek ${ }^{2}$ and Alessandro Ruggiero ${ }^{1}$ (] \\ 1 Department of Industrial Engineering, University of Salerno, Via Giovanni Paolo II, $\mathrm{n}^{\circ} 132$, \\ 84084 Fisciano, Italy; ruggiero@unisa.it \\ 2 Department of Material Science and Manufacturing Technology, Faculty of Engineering, \\ Czech University of Life Sciences Prague, 16500 Prague, Czech Republic; valasekp@tf.czu.cz \\ * Correspondence: mmilosevic@unisa.it; Tel.: +39-348-243-6145
}

Received: 21 January 2020; Accepted: 2 April 2020; Published: 4 April 2020

check for updates

\begin{abstract}
In the framework of green materials, in recent years, natural fiber composites attracted great attention of academia and industry. Their mechanical and tribological characteristics, such as high strength, elasticity, friction, and wear resistance, make them suitable for a wide range of industrial applications in which issues regarding a large amount of disposal are to be considered since their environmental friendliness gives them an advantage over conventional synthetic materials. Based on the recent and relevant investigations found in the scientific literature, an overview focused on the tribological characteristics of composite materials reinforced with different types of natural fibers is presented. The aim is to introduce the reader to the issues, exploring the actual knowledge of the friction and wear characteristics of the composites under the influence of different operating parameters, as well as the chemical treatment of fibers. The main experimental tribological techniques and the main used apparatus are also discussed, with the aim of highlighting the most appropriate future research directions to achieve a complete framework on the tribological behavior of many possible natural fiber composite materials.
\end{abstract}

Keywords: composite materials; natural fibers; tribology; wear; friction

\section{Introduction}

One of the main reasons for material failure and equipment damage is recognized to be tribological phenomena in terms of friction and wear [1]. The impact of tribological contacts on energy consumption is approximately $23 \%$ relative to global consumption; $20 \%$ of this energy consumption [2] is spent avoiding friction and $3 \%$ is used in the reproduction of damaged equipment and spare parts due to wear. Holmberg et al. [3] also investigated the economic and environmental effect of tribological phenomena related to the mining industry. It was found that friction and wear in the process of mineral mining cause annual losses of 210,000 million Euros, where $40 \%$ is spent to overcome friction. On the other hand, worldwide annual $\mathrm{CO}_{2}$ emission due to friction and wear in the mining industry reached 970 million tons, which is $2.7 \%$ of world emissions [3]. By tribological research and insights, losses caused by wear and friction of two solid bodies in relative motion can be significantly reduced. The increase of efficiency, productivity, reliability, safety, and the reduction of breakdowns of technical systems are major advantages of tribological investigations [4].

Nowadays, scientists are focused on the development of new "green" materials that are economical and environmentally friendly, which will meet the required properties of synthetic materials also from a tribological point of view. In this scenario, composite, and in particular natural fiber composite, materials are attracting attention both for academia and industry. 
Of course, natural materials were well known in ancient times when people survived using resources from nature. The first tools in history, arrows, knives, spoons, etc., were made by natural materials, wood, and stones. For thousands of years, natural materials were used to secure human existence. It is not known when composite materials were used for the first time, but some of the earliest records of their use date from the old Egyptian civilization. Additionally, the use of composites by Inca and Mayan civilizations has been recorded [5]. Wood and straw fibers were used in Ancient Greece to provide higher stability of traditional mortars [6]. To reduce cracks and enhance bonding, in Indo-Muslim architecture jute and straw fibers were used [7]. The last century was marked by industrial revolutions, technical progress, especially in energy and military sectors and, as a result, materials such as wood, stone, and plants did not have a primary role, and synthetic materials were produced en masse with a high growth level.

The impact of synthetic materials on the environment and the greenhouse effect are widely known. The negative behavior of these materials has been investigated [8-10]. The consciousness of environmental protection and more and more rigorous political regulations forced both industry and academia to think about new alternative materials that will meet all necessary properties. Except for their application in the construction industry, which has never stopped, natural fiber-reinforced composites (NFRCs) are again in focus. Numerous engineering fields increasingly employ NFRCs in their processes, intending to reach high business performances and ensure their competitiveness. Nowadays, the application of NFRCs is growing rapidly in the automotive industry, construction, packing, furniture, airplane industry, and so forth [11].

In general, NFRCs should be made by several kinds of natural fillers, such as plant fiber, animal fiber, and mineral fiber. On the basis of [12] a schematic representation can be found in Figure 1.

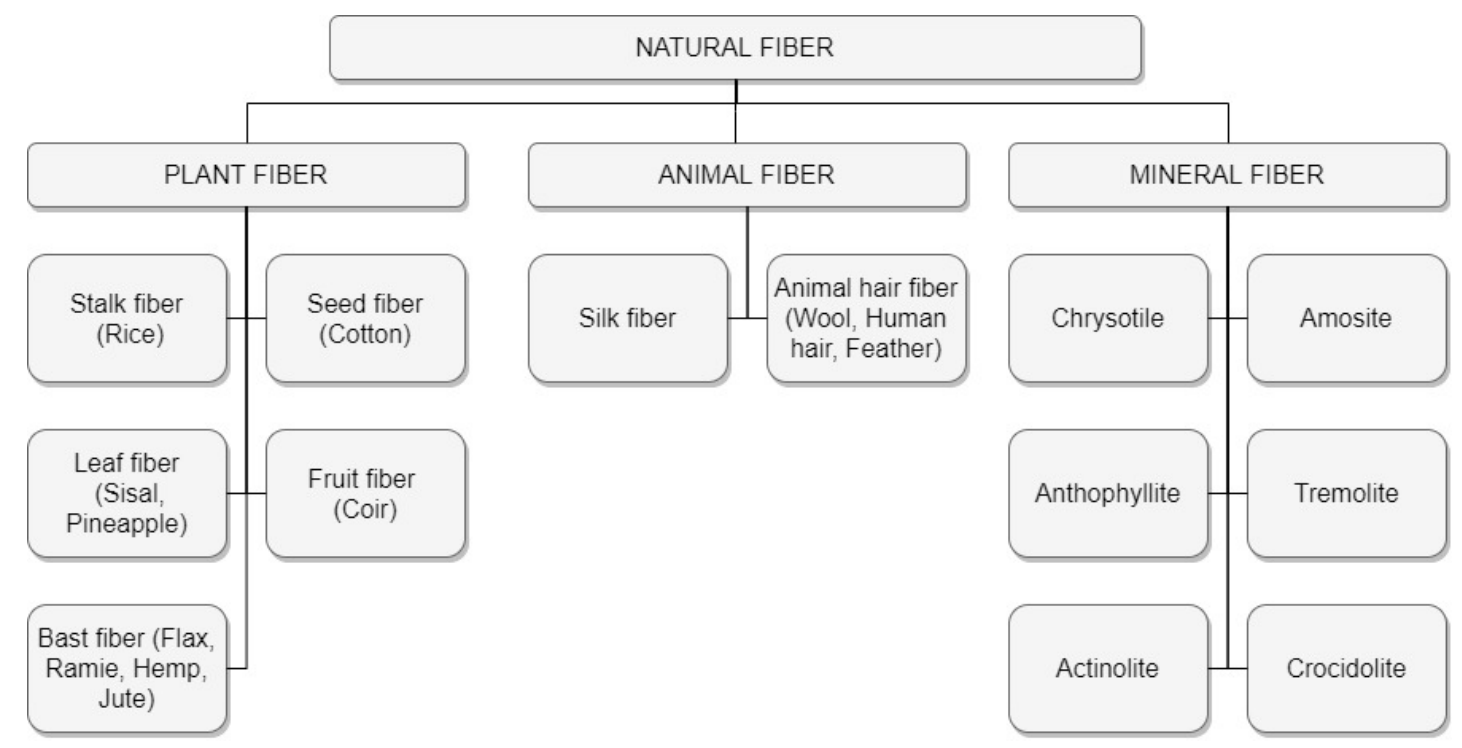

Figure 1. Classification of natural fiber.

While maintaining the high stiffness-to-weight and high specific strengths found in synthetic fiber-reinforced composite materials (SFRCs), NFRCs also have the beneficial properties of non-abrasiveness, low material cost, recyclability, biodegradability, and $\mathrm{CO}_{2}$ neutrality [13-16]. However, some types of natural fibers as reinforcement have certain drawbacks. Poor resistance to moisture, the formation of aggregates during processing, and incompatibility with the hydrophobic polymer matrix are some of the issues with a negative impact of the tribo-mechanical properties of composites [17].

These disadvantages have a high impact on the tribological properties of composite materials reinforced with natural fibers, such as friction and wear. As such, friction and wear tests of NFRCs 
are crucial for the efficiency of tribological systems. To ensure working conditions identical to the real application of tribological pairs, it is necessary to perform simulations of the investigated system. In this process, selecting geometry, relative motion, and imposed loads (contact pressure) are the most important for proper simulation of wear conditions [4]. Usually, for sliding contacts three types of geometry are employed in tribo testing: line contact, where the most common tribosystem is cylinder-on-disk; point contact, with ball-on-disk as a representative; and conforming contact, such as flat-on-flat. With the aim to give a useful organic overview on the state of the art of the scientific literature on natural fiber-reinforced composite materials, the authors will focus on investigations found in the relevant literature on the behavior of such materials regarding sliding friction and wear tests. Fiber-matrix proportion, fiber treatment, orientation into the composite, fiber type, etc., will be considered.

\section{Tribology in NFRCs}

The selection of suitable contact materials and lubricants, if any, is crucial for the efficiency and reliability of a mechanical systems. Tribologists are usually focused on the contact between two bodies [18]. Without physical contact, friction and wear cannot occur [19]. Popov et al. [19] concluded that the normal contact is a basic prerequisite for all other phenomena in tribology science, defining two the most important relationships of the normal contact theory:

1. The dynamic properties of the system and stiffness of the contact are determined by the relationship between the normal body displacement and the normal force; and

2. In the contact area, stresses occur.

From a geometric point of view, due to the relative motion of two contact surfaces, two basic types of macro contact can be defined: conformal and non-conformal [20]; according to [21,22] the difference between them is in the stress-strain extent.

Throughout history, from Da Vinci, Amontons, Euler, to Hertz, Reynolds and Archard, the phenomenon of contact has been studied, accompanied by friction. It is known the friction leads to energy dissipation. In micro contacts, the presence of friction can cause micro fractures and surface wear [18]. Moreover, many studies proved that thermal regimes and stress states have an influence on the variation of tribological properties during the exploitation of mechanical systems [23-27]. It is widely known that heat conducted by frictional work during the wear processes increases the interface temperature of contacting bodies. It was confirmed by Lim and Ashby [28] that increased interface temperature can change the mechanical properties of the sliding surfaces. In the paper of Amiri and Khonsari [29] they recorded that the changing of mechanical properties caused by increasing interface temperature drastically influence the tribological behavior of contact pairs.

With particular reference to the tribological behavior of NFRCs materials, studies conducted on this topic show that natural fibers, because of their good mechanical properties, as collected in Table 1 , mixed with the matrix contribute to the improvement of tribo-mechanical characteristics [30-36]. The wear resistance is also largely dependent on the distribution of the fibers in the matrix, not only natural, within the material relative to the direction of contact of the contact pair. Liang et al. [37] investigated the influence of fiber orientation within the composite on the tribological behavior of the material.

As schematically shown in Figure 2 and clarified by many authors [40-45], with respect to the sliding direction, three fiber orientations within composites should be defined in a tribological contact: (a) Parallel orientation (P-O), (b) anti-parallel orientation (AP-O) and (c) normal orientation (N-O). 
Table 1. Mechanical properties of some natural fibers compared with Aramid and E-glass fibers [38,39].

\begin{tabular}{ccccc}
\hline Fiber & $\begin{array}{c}\text { Tensile Strength } \\
\mathbf{( M P a})\end{array}$ & $\begin{array}{c}\text { Young's Modulus } \\
\mathbf{( G P a )}\end{array}$ & $\begin{array}{c}\text { Elongation at } \\
\text { Break } \mathbf{( \% )}\end{array}$ & Density $\left(\mathbf{g} / \mathbf{c m}^{\mathbf{3}} \mathbf{)}\right.$ \\
\hline Abaca & 400 & 12 & $3-10$ & 1.50 \\
Alfa & 350 & 22 & 5.80 & 0.89 \\
Bagasse & 290 & 17 & - & 1.25 \\
Bamboo & $140-230$ & $11-17$ & - & $0.60-1.10$ \\
Banana & 500 & 12 & 5.90 & 1.35 \\
Coir & 175 & $4-6$ & 30 & 1.20 \\
Cotton & $287-597$ & $5.50-12.60$ & $7-8$ & $1.50-1.60$ \\
Curaua & $500-1150$ & 11.80 & $3.70-4.30$ & 1.40 \\
Date palm & $97-196$ & $2.50-5.40$ & $2.0-4.50$ & $1.0-1.20$ \\
Flax & $345-1035$ & 27.60 & $2.70-3.20$ & 1.50 \\
Hemp & 690 & 70 & 1.60 & 1.48 \\
Henequen & $500 \pm 70$ & $13.20 \pm 3.10$ & $4.80 \pm 1.10$ & 1.20 \\
Isora & $500-600$ & - & $5-6$ & $1.20-1.30$ \\
Jute & $393-773$ & 26.50 & $1.50-1.80$ & 1.30 \\
Kenaf & 930 & 53 & 1.60 & - \\
Nettle & 650 & 38 & 1.70 & - \\
Oil palm & 248 & 3.20 & 25 & $0.70-1.55$ \\
Piassava & $134-143$ & $1.07-4.59$ & $21.90-7.80$ & 1.40 \\
Pineapple & 1.44 & $400-627$ & 14.50 & $0.80-1.60$ \\
Ramie & 560 & 24.50 & 2.50 & 1.50 \\
Sisal & $511-635$ & $9.40-22.0$ & $2.0-2.50$ & 1.50 \\
Aramid & $2700-4500$ & 130 & $3.30-3.70$ & 1.45 \\
E-glass & 3400 & 72 & - & 2.50 \\
\hline
\end{tabular}

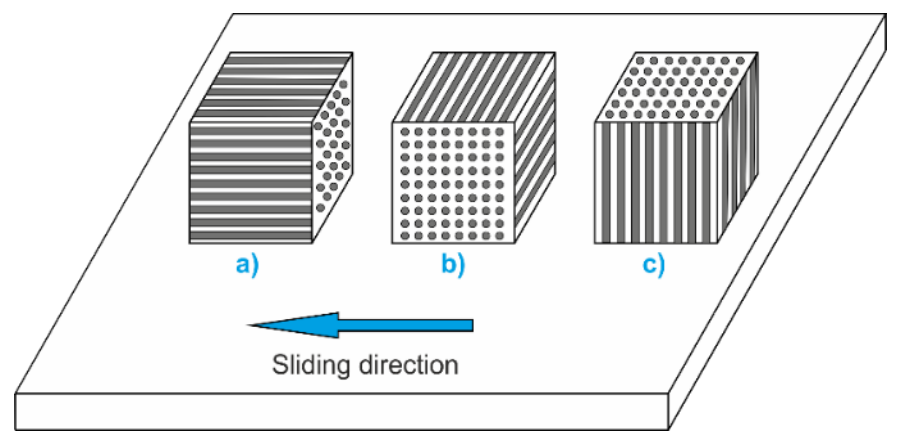

Figure 2. Fiber orientations: (a) Parallel, (b) anti-parallel, and (c) normal, with respect to the sliding direction.

The presented fiber orientations and their influence on the tribological properties of the NFRCs will be discussed in Section 3.

Simulation of the tribo-contacts in a particular machine, evaluation of the influence of the lubricants for a particular application, investigation on the causes of the friction, etc., are some of the purposes of tribo-testing laboratory techniques. It is widely known that the tribometers represent the most commonly used devices to measure friction and wear [46]. To avoid measurement errors and simulate real systems, it is necessary to carefully select the tribometer and set up experimental conditions, as well as the post-processing of measured data [47]. From the analysis of literature on the NFRCs tribo-contact emerges the most used common tests apparatus, like pin-on-flat, flat-on-flat, pin-on-rotating disk, ball-on-flat, ball-on-disk, etc.

The typical application of the apparatus implies sliding wear of various NFRC's materials with the contact between specimen and its counterface. As one of the most used apparatus [46], and commonly used to investigate the tribological behavior of NFRCs [48], the Pin/Ball-on-Disk configuration, 
illustrated in Figure 3a operates by closing the pin/ball against a rotating disk and applying on the pin/ball a normal load. Contact can occur on the disk's flat surface or on the circumference of the disk. Depending on the type of tests, the dimensions of the pin/ball and disk may vary according with the desired mean contact pressure. In reciprocating tribometers, presented in Figure $3 \mathrm{~b}$, the pin/ball moves along the horizontal stroke following a linear trajectory coupled with a flat surface. The parameters to set such as frequency, time, normal load, stroke, lubricant type, and temperature, if any, provide both the measurement of the kinetic friction coefficient and the possibility to investigate the specimen's wear phenomena [49].

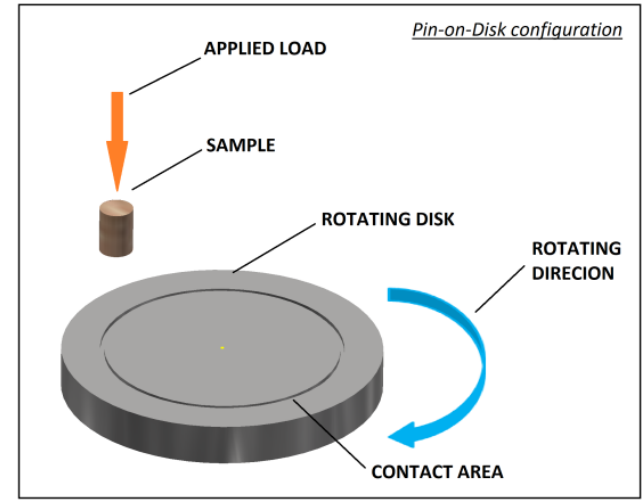

(a)

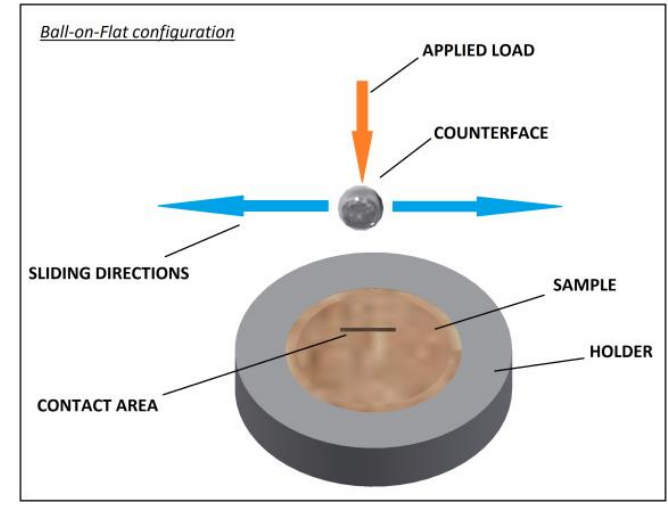

(b)

Figure 3. Pin-on-disk configuration (a) and reciprocating ball-on-flat configuration (b).

\section{Friction and Wear of NFRCs}

Under dry and wet sliding conditions the friction and wear of natural fiber composite materials have been investigated by several scientists [30,50-58]. Tribological properties of NFRCs are influenced by numerous factors, such as operating conditions, type of matrix, fiber contents, orientation, and chemical treatments. Investigations were found in the literature on polymeric composites reinforced with kenaf, jute, oil palm, and coconut (coir) fibers. Even if more NFRCs are be created, they should be investigated for deeper understanding of their tribo-mechanical properties. An overview based on the analysis of the scientific literature on different NFRCs is presented below.

\subsection{Kenaf Fiber NFRCs}

Kenaf (Hibiscus cannabinus L.) is a 4000 year old annual plant which requires a warm environment for effective growth. In the beginning, kenaf was used for the production of rope, sackcloth, and paper [54,59]. The favorable tribo-mechanical characteristics of kenaf fiber as reinforcement material of polymer composites allow wide application. The application of kenaf fibers nowadays extends from the textile industry, through the automotive and construction industries, to the electronic industry $[30,54,55,60,61]$. The automotive industry delivers strict requirements in terms of material properties used in production processes, such as cost, lightweight, safety and crashworthiness, and recycling and life-cycle consideration. Advantages of kenaf plant compared with other lignocellulosic fiber plants are its adaptivity to environmental conditions, short plantation cycle, and lower level of chemical treatment of pesticides and herbicides $[62,63]$. The chemical composition of the most employed natural fibers is presented in Table 2. 
Table 2. Chemical composition of some major natural fibers [64,65].

\begin{tabular}{|c|c|c|c|c|c|}
\hline Fiber & $\begin{array}{l}\text { Cellulose } \\
(w t \%)\end{array}$ & $\begin{array}{l}\text { Hemicellulose } \\
(w t \%)\end{array}$ & Ligning (wt $\%)$ & Pectin (wt\%) & Waxes $(w t \%)$ \\
\hline Abaca & 62.5 & 21 & 12 & 0.8 & 3 \\
\hline Alfa & 45.4 & 38.5 & 14.9 & - & 2 \\
\hline Bagasse & 37 & 21 & 22 & 10 & - \\
\hline Banana & 62.5 & 12.5 & 7.5 & 4 & - \\
\hline Bamboo & 34.5 & 20.5 & 26 & - & - \\
\hline Coir & 46 & 0.3 & 45 & 4 & - \\
\hline Cotton & 89 & 4 & 0.75 & 6 & 0.6 \\
\hline Curaua & 73.6 & 5 & 7.5 & - & - \\
\hline Flax & 70.5 & 16.5 & 2.5 & 0.9 & - \\
\hline Hemp & 81 & 20 & 4 & 0.9 & 0.8 \\
\hline Henequen & 60 & 28 & 8 & - & 0.5 \\
\hline Isora & 74 & - & 23 & - & 1.09 \\
\hline Jute & 67 & 16 & 9 & 0.2 & 0.5 \\
\hline Kapok & 13.16 & - & - & - & - \\
\hline Kenaf & 53.5 & 21 & 17 & 2 & - \\
\hline Nettle & 86 & 10 & - & - & 4 \\
\hline Oil palm (EFB) & $36-65$ & $22-30$ & $18-25$ & - & - \\
\hline Phormium & 67 & 30 & 11 & - & - \\
\hline Piassava & 28.6 & 25.8 & 45 & - & - \\
\hline Pineapple & 80.5 & 17.5 & 8.3 & 4 & - \\
\hline Ramie & 72 & 14 & 0.8 & 1.95 & - \\
\hline Sisal & 60 & 11.5 & 8 & 1.2 & - \\
\hline
\end{tabular}

To determine fibers with the best mechanical characteristics necessary for the production and functionality of the automotive friction brake systems, Ashafi'e et al. [66] used an analytical method based on a weighted decision matrix (WDM) to categorize natural fibers, such as jute, kenaf, ramie, and asbestos fibers. Kenaf was identified as the most suitable material which meets the requirements to be employed as a reinforcement of these automotive composite components.

Fiber orientation in the matrix is recognized as having a strong influence on wear behavior $[30,54,55]$. In [57] the tribological application of kenaf/epoxy composite (KEC) under wet contact conditions was investigated. The authors used a block-on-disk (BOD) configuration to test samples against a stainless steel disc counterface. Water was used as a wear debris cleaner from the rubbing area and to dissipate the heat generated by friction. In the matrix, fibers were oriented in three standard configurations: (i) normal orientation (N-O), (ii) parallel orientation (P-O), and (iii) anti-parallel orientation (AP-O), with respect to the sliding direction. The specific wear rate $\left(W_{s}\right)$ of KEC is calculated by Equation (1):

$$
W_{s}=\frac{\Delta m}{L \cdot \rho \cdot F^{\prime}}
$$

where $W_{s}$ is the specific wear rate $\left(\mathrm{mm}^{3} / \mathrm{Nm}\right), \Delta m$ is the weight loss $(\mathrm{g}), L$ is the sliding distance $(\mathrm{m}), \rho$ is the density $\left(\mathrm{g} / \mathrm{mm}^{3}\right)$, and $F$ is the applied load $(\mathrm{N})$. The authors concluded that the samples with fibers oriented in $\mathrm{N}-\mathrm{O}$ exhibited significant wear resistance by about $35-57 \%$ compared with $\mathrm{P}-\mathrm{O}$ and AP-O fibers. It was noticed that in $\mathrm{N}-\mathrm{O}$, when a $150 \mathrm{~N}$ applied load was employed, there is a strong adhesion of the end of the fibers and the matrix which influences no pulling out, debonding, and/or peel. In other words, kenaf fibers oriented in $\mathrm{N}-\mathrm{O}$ provide strong support of epoxy composites due to their resistance to the rubbing process. Higher friction coefficients were reported in KEC tested in N-O and AP-O. In general, the COF values vary from 0.03 to 0.045 and because of presence of water as a debris cleaner, essentially, it leads to low friction between contact materials.

In [67], using an ASTM B 611 machine, under the applied loads of 5-20 N, at a rotation speed of the disk of $100 \mathrm{rpm}$ for $300 \mathrm{~s}$ duration, the authors investigated the three-body abrasive wear of KEC considering three standard fiber orientations. The tests were conducted using a dry sand/steel wheel 
apparatus with small, intermediate, and large sand particles. The tests were also conducted on neat epoxy (NE) to compare the tribological behavior with the KEC. Reduction in the wear rate by about $50-75 \%$ was found with the N-O fiber orientation and significantly lower than NE. In general, a low friction coefficient value $(\approx 0.05-0.12)$ was noticed. Due to the homogeneity of the asperities in contact, the lower value of the friction coefficient in the NE was determined.

Narish et al. [68] investigated kenaf fibers in polyurethane (PU), tested on abrasive wear behavior, in all three standard fiber orientations. For P-O and applied loads of 50-60 N, W s was below the value of $10 \times 10^{-8} \mathrm{~mm}^{3} / \mathrm{Nm}$, while $W_{\mathrm{s}}$ exhibited the lowest rate with ranges between $2 \times 10^{-8}$ and 5.25 $\times 10^{-8} \mathrm{~mm}^{3} / \mathrm{Nm}$ when the fibers were in $\mathrm{AP}-\mathrm{O}$ and $\mathrm{N}-\mathrm{O}$, respectively. The authors reported kenaf fiber/polyurethane provided better wear performances compared to neat PU. On the friction properties of kenaf/polyurethane (0.2-0.65) no significant effects of fiber orientation were found.

Regarding the influence of imposed load on the tribological characteristics of kenaf fiber composites, with a not highly significant effect, the applied load was found to influence their behavior. In the same study [67], the authors also investigated the wear rate versus the applied load during tests. Two values of applied load were employed, $5 \mathrm{~N}$ and $20 \mathrm{~N}$. The wear rate of epoxy reinforced AP-O and P-O kenaf fibers using intermediate and large sand particles, showed a higher wear under lower applied load while, for the same applied load and sand particles, the wear rate of NE and KEC showed a lower value than when small particles were used.

The specific wear rate was also determined according to the Archard wear model (2) [58], and investigated by Nordin et al. [56] by using an Abrasion Resistance Tester (TR-600) to highlight the difference of the tribological behavior of kenaf polyester composite (KPC) with respect to kenaf epoxy composite (KEC).

$$
Q=\frac{K W L}{H}
$$

In Equation (2) $Q$ is the total volume of wear debris produced, $K$ is a dimensionless constant, $W$ is the total normal load, $L$ is the sliding distance, and $H$ is the hardness of the softest contact surface. The comparison of sliding (abrasive) distance vs. the specimen's mass loss and vs. the specimen's specific wear rate, respectively, with different applied loads (5-20-30 N) and a constant sliding velocity of 14 $\mathrm{m} / \mathrm{s}$ were investigated. In [56], the authors concluded that for both materials, for high applied loads, increasing the sliding distance, the mass loss increases significantly, up to about 12 and $14 \mathrm{~g}$ for KPC and KEC, respectively. For low applied load, the mass loss for both KPC and KEC is almost negligible (about $2 \mathrm{~g}$ ). Experimental results show two phases of specific wear rate behavior. The first, initial phase, where the specific wear rate suddenly decreases from $6 \times 10^{-2}$ to less than $1 \times 10^{-2} \mathrm{~mm}^{3} / \mathrm{Nm}_{\text {, }}$ the authors explained this as normal behavior of the investigated NFRC materials. They indicated this phenomenon is caused by the initial running-in of the tribosystem. Increasing the sliding distance establishes the second phase. A specific wear rate decreases until it achieves a constant value. This phenomenon is due to the formation of a smoother surface after the running-in is complete.

Regarding the effect of fibers' chemical treatments on the tribology of NFRCs based on kenaf, to improve their (but also of many types of NFRCs) mechanical properties various chemical methods like silane treatment, acetylation, grafting, etc., should be used [69]. Chemical modification of kenaf fibers was investigated in [59] using $\mathrm{NaOH}$ : at different concentrations at room temperature for $3 \mathrm{~h}$ the kenaf fibers were soaked into 3\%,6\%, and $9 \% \mathrm{NaOH}$. The authors found that the modified fibers provided better mechanical properties than untreated fibers. In [35] an analysis and comparison of tribological properties of kenaf/epoxy and oil palm/epoxy composites under dry sliding conditions was conducted. Both oil palm and kenaf fibers were soaked in natrium hydroxide $(\mathrm{NaOH})$ at a maintained temperature of $26 \pm 2^{\circ}$ for $48 \mathrm{~h}$. Composite samples were made in a fiber ratio of $30 \mathrm{wt} \%, 50 \mathrm{wt} \%$, and $70 \mathrm{wt} \%$ mixed with epoxy. Wear tests were conducted according to the ASTM G99-05 standard using a pin-on-disc configuration against a polished steel disc with a $49.05 \mathrm{~N}$ applied load, a disk angular velocity of 1000 RPM, with different controlled temperatures of $23,50,100$, and $150{ }^{\circ} \mathrm{C}$. At high temperature, the hardening degradation of material was noticed, which causes a higher specific 
wear rate (about $250 \times 10^{-5}$ and $200 \times 10^{-5} \mathrm{~mm}^{3} / \mathrm{Nm}$ ) of kenaf fiber/epoxy and oil palm fiber/epoxy composites, respectively. A lower specific wear rate of oil palm fiber/epoxy than the kenaf fiber/epoxy composite was recorded. Considering the fiber composition, the authors concluded that, by increasing the weight ratio of the kenaf fiber within the composite, the wear performances increase. In contrast, the wear performances decrease with an increasing weight ratio of oil palm fiber.

\subsection{Jute Fiber NFRCS}

From the bast fiber category, jute (Corchorus olitorius and Corchorus capsularis L.) is composed of cellulose and lignin. Commonly used in the textile and construction industries, jute fibers are, nowadays, in high expansion and their application has extended to household items, the automotive industry, and other industries that allow the use of natural materials such as jute. Considering the fiber orientation and fiber content, as presented in Table 3, Acha et al. [70] reported the compressive properties of unsaturated polyester reinforced with raw, acetone-washed, and detergent-washed jute fibers.

Table 3. Compressive properties of jute composites [70].

\begin{tabular}{|c|c|c|c|c|c|}
\hline Sample & $\begin{array}{c}\text { Fiber Orientation } \\
{\left[{ }^{\circ}\right]}\end{array}$ & $\begin{array}{l}\text { Fiber Content } \\
{[w \mathrm{w} \%]}\end{array}$ & $\begin{array}{l}\text { Modulus } \\
\text { [Gpa] }\end{array}$ & $\begin{array}{c}\text { Maximum } \\
\text { Stress [Mpa] }\end{array}$ & $\begin{array}{c}\text { Maximum Strain } \\
{[\mathrm{mm} / \mathrm{mm}]}\end{array}$ \\
\hline Matrix & - & 0 & $2.5 \pm 0.04$ & $111.4 \pm 4.05$ & $0.305 \pm 0.070$ \\
\hline \multirow[t]{3}{*}{ Raw } & 0 & 56 & $2.3 \pm 0.3$ & $52.4 \pm 1.0$ & $0.041 \pm 0.008$ \\
\hline & 30 & 53 & $1.8 \pm 0.3$ & $53.8 \pm 6.1$ & $0.045 \pm 0.007$ \\
\hline & 45 & 56 & $1.3 \pm 0.1$ & $57.4 \pm 2.4$ & $0.056 \pm 0.005$ \\
\hline \multirow[t]{3}{*}{ Acetone-washed } & 0 & 54 & $1.8 \pm 0.3$ & $66.8 \pm 13.2$ & $0.040 \pm 0.010$ \\
\hline & 30 & 53 & $1.7 \pm 0.5$ & $70.9 \pm 7.6$ & $0.050 \pm 0.010$ \\
\hline & 45 & 55 & $2.1 \pm 0.5$ & $84.1 \pm 1.7$ & $0.060 \pm 0.010$ \\
\hline \multirow[t]{3}{*}{ Detergent-washed } & 0 & 48 & $1.7 \pm 0.4$ & $60.5 \pm 4.2$ & $0.050 \pm 0.005$ \\
\hline & 30 & 51 & $1.8 \pm 0.4$ & $64.8 \pm 5.3$ & $0.052 \pm 0.016$ \\
\hline & 45 & 46 & $1.6 \pm 0.5$ & $63.0 \pm 7.1$ & $0.045 \pm 0.005$ \\
\hline
\end{tabular}

Considering the effect of fiber orientation on the material wear performances, respect to the sliding directions, Alshammari et al. [44] investigated jute/epoxy composites using block-on-ring (NFRC vs. stainless steel) configuration under dry contact conditions. The AP-O fibers showed a better film generating on the contact surface and a high shear resistance, allowing the authors to conclude that the AP-O fibers within epoxy matrix exerted a high friction coefficient $(0.72 \pm 0.13)$. However, for $\mathrm{N}-\mathrm{O}$, due to high material removal from the surface, a low level of friction force during tests was noted and the average friction coefficient was about $0.4 \pm 0.11$.

Unsaturated polyester was used in [71] as the composite matrix reinforced with the jute fibers. By using the pin-on-disk configuration, friction and wear tests were conducted. An increase in the fiber volume fraction to $33 \%$ caused a friction coefficient increase by about $14 \%$ when the jute fibers are in the $\mathrm{N}-\mathrm{O}$ orientation, with respect to the sliding direction, while the wear rate is decreased by about $95 \%$. When oriented in the $\mathrm{P}-\mathrm{O}$ and AP-O, no significant change of friction coefficient was noticed and the wear rate decreased by about $72 \%$.

Regarding the effect of the applied load, the three different types of jute/polypropylene composites (JPPCs) at different applied loads in order to compare the measured wear rates were investigated [72]. Two-body abrasion tests were conducted on untreated, solution-treated, melt-mixed JPPCs, and pure PP with applied loads of 1,3,5, and $7 \mathrm{~N}$ against the rotating wheel, on which 400 grit abrasive paper was employed. More material was removed from the NFRC at ther $7 \mathrm{~N}$ load due to deeper grooving in the sample, which allows one to conclude that the wear rate increases with the increase of the applied load.

Respecting the sliding distance $(0-3000 \mathrm{~m})$, at the different applied loads $(10,20,30 \mathrm{~N})$ and sliding velocities $(1,2,3 \mathrm{~m} / \mathrm{s})$, in the research by Yallew et al. [31], the high variability of the friction coefficient, from about $0.3-0.6$ of the JPPCs occurs. The decrease in the friction coefficient occurs when an applied load increases during sliding. This can be because of the formation of thermal gradients 
due to non-uniform temperature dissemination. The thermal stresses debilitate the fiber characteristics and matrix which causes filaments to be slack and easily shearable. Pulling out and fiber separations during sliding bring down the coefficient of friction.

Dwivedi and Chand [73] reported the effect of the applied load and fiber orientation of the jute/polyester composite and discovered a positive behavior of the friction coefficient in all orientations when the applied load was in a growing trend. In general, with the increase of the applied load from 20 to $60 \mathrm{~N}$, the friction coefficient decreased from about 1.1 to 0.55 .

Focusing on the effect of fiber chemical treatment, in [74] the authors investigated the tribological behavior of jute/hazelnut shells and jute/graphite composite. The chemical treatment of jute, as shown in Figure 4, two SEM images (obtained in Czech University of Life Sciences Prague, Faculty of Engineering, Department of Material Science and Manufacturing Technology, Prague, Czech) of treated and untreated jute fiber, and hazelnut, subjected to soaking in $12 \%$ and $25 \%$ of $\mathrm{NaOH}$, respectively. Then, jute fibers were treated in the $1 \mathrm{M} \mathrm{HCl}$ steam for $30 \mathrm{~min}$, and $\mathrm{KH} 550$ silane coupling agent was used with additional stirring with hazelnut shells for $2 \mathrm{~h}$. During the initial baseline period of the tests, conducted by a JF160 CHASE friction test machine, samples containing jute fibers (14.6\% vol.) showed the lower value of the friction coefficient $(\mu=0.614)$ in comparison with samples without jute $(\mu=0.708)$.

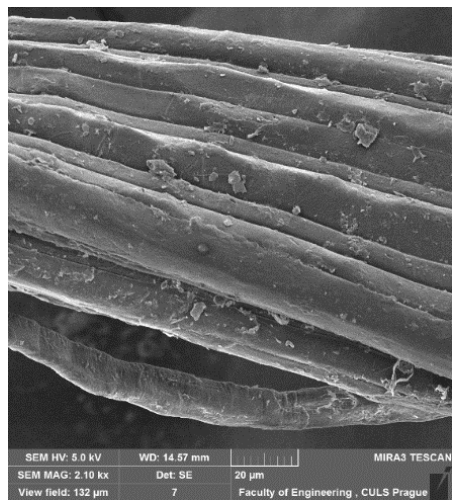

(a)

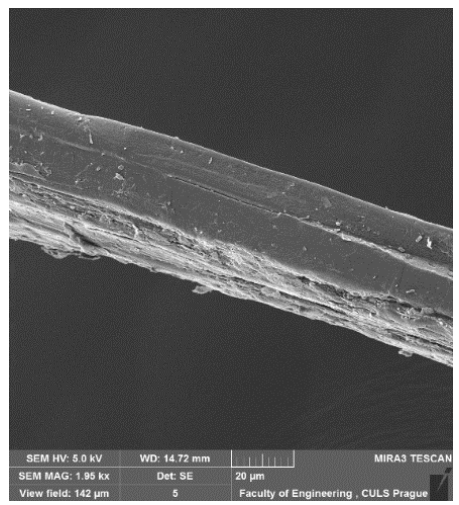

(b)

Figure 4. SEM images of jute fibers: (a) detail of jute fiber without surface treatment; (b) treated jute fiber.

By using a particular abrasion tester (SUGA) the effect of the MA-g-PP coupling agent on the wear performances of jute/polypropylene composite was investigated in [72]. Caused by the improved fiber-matrix adhesion, which resulted by the addition of MA-g-PP, the abrasion resistance increased. The abrasive wear sensitivity on the fiber-matrix adhesion was identified in [33]. The authors investigated abrasive wear performances of jute/polylactide composite treated with five different substances: (i) untreated surface, (ii) alkalization, (iii) permanganate treatment, (iv) peroxide treatment, (v) silane 1 (3-amino propyl trimethoxy silane), and (vi) silane 2 (trimethoxy methyl silane) treatment. Abrasive wear tests for each of the differently-treated samples was conducted using a pin-on-disk configuration. On the disk was installed 600 grit abrasive paper. Experimental research showed that the surface treatment increased the interfacial adhesion, which has strong impact on the wear resistance of jute/polylactide composite. The authors showed that the sample treated with silane 2 in comparison with the others treatment substances exhibited the best abrasive wear resistance, with about $50 \%$ less weight loss than others.

\subsection{Oil Palm Fiber NFRCs}

Cultivated in 42 countries on 11 million hectares worldwide, the oil palm provides the highest yielding edible oil in the world [50]. Oil palm trees can be utilized as a source of fibers in the manufacturing of composites for wide applications. It is known that the extracted empty fruit bunch 
(EFB) of the oil palm plant is one of the largest sources of oil palm fibers, up to $73 \%$ of fiber yield [75-79]. EFB consists of approximately $22 \%$ of the total palm oil industry waste $[75,80]$. In the review paper, Shinoj et al. [76] reported that EFB waste can be a useful gradient for biocomposites. No relevant investigations were found in the literature regarding investigations of fiber orientation influence on the tribological behavior of the corresponding NFRC materials. The influence of the applied load on wear and frictional properties was investigated in [51]. The authors focused on the frictional and wear behavior of the polyester composite reinforced with treated and untreated oil palm fibers. Against a polished stainless steel counterface, the composite samples were tested utilizing a block-on-ring configuration under dry contact conditions. Applying different load ranges, from $30 \mathrm{~N}$ to $100 \mathrm{~N}$, they concluded that when the values of the applied loads are of intermediate values between $50 \mathrm{~N}$ and $70 \mathrm{~N}$, the specific wear rate exhibits a lower value of about $1.2 \times 10^{-5} \mathrm{~mm}^{3} / \mathrm{Nm}$ in comparison with low and high applied load values of $30 \mathrm{~N}$ and $100 \mathrm{~N}$, where the $W_{\mathrm{s}}$ is about $2 \times 10^{-5} \mathrm{~mm}^{3} / \mathrm{Nm}$. This behavior should be attributed to the gap due to the debonding of the fiber at an intermediate applied load. The authors reported a significant influence of a high applied load on the friction coefficient of oil palm/polyester composite. With the increase of the applied load, the friction coefficient increased. A significant effect of the applied load on wear behavior is studied in [81]. On the same sample materials as in [51], Yousif and El-Tayeb reported a positive abrasive wear resistance with the increase in the applied load. They investigated three-body abrasive wear behavior under different operating parameters. However, due to debonding and pulling out the fibers caused by the negative adhesion properties of untreated oil palm fibers, the high applied load caused an increased wear rate.

Regarding the tribological behavior of polymer composites reinforced with natural fibers, such as the effects of fiber chemical treatments on it, several papers were published [36,51,75,81]. Using a block-on-ring configuration, Yousif and El-Tayeb [51] investigated the tribological behavior of alkali-treated $(6 \% \mathrm{NaOH})$ and untreated oil palm/polyester composites. Under dry sliding contact conditions friction and wear tests were performed considering variable operating parameters. Due to the enhanced adhesion between the oil palm fibers and polyester resin, the treated oil palm/polyester composite reached a greater wear resistance of about $11 \%$ than the untreated composite samples tested under the same conditions. Moreover, in [81] the three-body abrasive wear was investigated using treated and untreated oil palm/polyester composites. A $6 \% \mathrm{NaOH}$ solution was used to modify the oil palm fiber surface. Both treated and untreated composites showed better tribological properties than neat polyester, but, because of low-composite porosity, $\mathrm{NaOH}$-treated samples provided lower abrasive wear rate than polyester reinforced with chemically untreated oil palm fibers.

\subsection{Coir Fiber NFRCs}

Obtained from the husk of the coconut palm tree, the coir fiber, the cheapest fiber in the world [53], is used for producing a wide variety of furniture materials, ropes, sacking, boats, and rugs [52]. Considering the coir fiber-based composites, the high lignin content of coir fibers causes good fiber water resistance, relatively waterproof and be chemically modified [82-84]. Good mechanical properties, such as elongation, allow tribological applications of composites reinforced with coir fibers [85]. Oriented in two different directions, parallel and normal to the sliding, in [86] brown and white coir fibers were investigated as a reinforcement of the epoxy matrix. The abrasive wear rate of the composites was considered. The authors reported the epoxy reinforced with normal-oriented coir fibers demonstrated increased wear resistance by about $5 \%$ in comparison with resin without fillers. To the best knowledge of the authors, no more relevant studies were found in the literature focusing on the influence of coir fiber orientations on the tribological performances of polymeric composite materials. To ensure better tribo-mechanical properties, materials, named hybrid composites, are of interest to both industry and academia. In [87], Kumar et al. used coconut coir, banana, and glass fibers as reinforcements of unsaturated polyester to investigate abrasive wear behavior under different operating parameters. Combining the fibers, four types of composite samples were made, coir/polyester, banana/polyester, coir/banana/polyester, and coir/banana/glass/polyester. With an 
applied load of 5-20 N, abrasive wear tests were conducted under dry contact conditions. It was reported that a higher wear rate of coir/polyester and banana/polyester occurs when the applied load increases than the other two sample types. This is due to improved composite strength caused by the presence of a hybrid combination.

Due to fast film transfer generated on the counterface, which causes the so-called back film transfer, at a higher applied load, the wear rate investigated in [88] showed better characteristics in comparison when the lower normal loads are applied. Ibrahem [89] reported that the coir fiber as a reinforcement in polyester resin behaves as a scratching tool on the contact area when increased an applied load from $4 \mathrm{~N}$ to $6 \mathrm{~N}$, which affects the decrease of the friction coefficient from 0.75 to 0.55 and from 0.62 to 0.43 , respectively.

Interfacial interaction improvement and roughening of the surface could be achieved by chemical treatment in the material preparation process. Employing two types of coir fibers (white and brown) as a reinforcement of epoxy resin and chemically treated with a $6 \% \mathrm{NaOH}$ solution, Valášek et al. [86] reported a significant improvement of tensile strength while abrasive wear resistance was not affected by $\mathrm{NaOH}$ treatment. However, the composite prepared of coir fibers treated by ferric nitrate $\mathrm{Fe}\left(\mathrm{NO}_{3}\right)_{3}$ and ammonium chloride $\mathrm{NH}_{4} \mathrm{Cl}$ salts and mixed with epoxy resin provided better abrasive wear resistance than pure epoxy composite at various sliding velocity and applied loads [90].

\subsection{Friction and Wear Behavior of Natural Fiber-Based vs. Synthetic Fiber-Based Composites}

Synthetic materials are widely used as fillers in various composites. Good mechanical properties, such as strength, stiffness, flexibility, and fire resistance, are some of advantages of the synthetic fibers and they are used as reinforcements to improve the tribological behavior of neat polymers [45,91-95]. However, the high cost and their impact on environmental pollution diminishes their advantage to be the leading fillers of polymer composites. To be environmentally friendly, to reduce the production cost, weight, and to improve the tribological properties, the synthetic fiber-based composites are being replaced by natural fiber composite materials. In recent years, the comparative analysis of the composite materials reinforced with natural and synthetic fibers, which can be found in Table 4, and their tribological behavior have been under investigation by many researchers [45,91].

Table 4. Specific wear rate and friction coefficient of NFRCs and SFRCs under different operating parameters.

\begin{tabular}{|c|c|c|c|c|c|c|c|}
\hline \multirow[b]{2}{*}{ Fiber } & \multirow[b]{2}{*}{ Matrix } & \multicolumn{3}{|c|}{ Operating Parameters } & \multirow[b]{2}{*}{$\begin{array}{c}\text { Wear Rate } \\
\left(\mathrm{mm}^{3} / \mathrm{Nm} \times\right. \\
\left.10^{-5}\right)\end{array}$} & \multirow[b]{2}{*}{ COF } & \multirow[b]{2}{*}{ Source } \\
\hline & & $\begin{array}{l}\text { Applied } \\
\text { Load (N) }\end{array}$ & $\begin{array}{c}\text { Sliding } \\
\text { Velocity }(\mathrm{m} / \mathrm{s})\end{array}$ & $\begin{array}{c}\text { Sliding } \\
\text { Distance } \\
(\mathbf{k m})\end{array}$ & & & \\
\hline Kenaf & Epoxy & $30-100$ & $1.10-3.90$ & $0-5$ & $0.15-2$ & $0.52-0.68$ & {$[30]$} \\
\hline Oil palm & Polyester & $30-100$ & $1.70-3.90$ & $0-5$ & $35-60$ & $0.60-0.92$ & [36] \\
\hline Cotton & Polyester & $20-80$ & 2.22 & 4 & $0.10-6$ & $0.60-1$ & [96] \\
\hline Sugarcane & Polyester & $20-80$ & 2.50 & 4.50 & $5000-10,000$ & $0.02-0.25$ & [45] \\
\hline Glass & Polyester & $30-100$ & $2.80-3.90$ & $0-14$ & $0.20-0.60$ & $0.40-0.60$ & [97] \\
\hline Carbon & Polyethylene & 4 & $1000-2500^{1}$ & - & - & $\approx 0.16$ & [92] \\
\hline $\begin{array}{l}\text { Organoclay } \\
\text { cloisite }\end{array}$ & Polyethylene & 30 & 0.682 & 0.0682 & $\approx 8-10$ & $\approx 0.09-0.11$ & [93] \\
\hline
\end{tabular}

${ }^{1}$ Sliding velocity unit is reported in [rpm].

To explore the tribo-potential of natural fibers as fillers of the thermoset polymers, in [49] is investigated adhesive wear resistance of sugarcane fiber/polyester composite (SCFP) and compared with glass fiber/polyester composite (GFP) samples. To be comparable, the tests were conducted under the same operating conditions. The strong variety in friction coefficient and wear rate was found, which depends on the fiber length into the composites. For the SCFP samples with 1, 5, and $10 \mathrm{~mm}$ fiber length it is reported that the wear rate decreased with the increasing length of fibers from 1 to $5 \mathrm{~mm}$. Employing the $10 \mathrm{~mm}$ fiber length, the wear rate increased. The wear rate decreased by $20-50 \%$ and the friction coefficient reduced to the lowest level (0.015) at high applied load when employing the 
$5 \mathrm{~mm}$ fiber length. However, an increased wear rate of $40-70 \%$ was recorded when the fiber length was $10 \mathrm{~mm}$.

In [91] the authors investigated the abrasive wear behavior of oil palm fiber/polyester composite (OPFP) in comparison with chopped strand mat glass fiber/polyester (CGFP). Against different grades of $\mathrm{SiC}$ abrasive paper $(400,1000$, and 1500) the samples were tested at atation speed of 50-100 rpm and applied loads of $5-20 \mathrm{~N}$ for a 3 min duration. Better tribological behavior was shown by OPFP, while CGFP contributes better mechanical characteristics.

The superiority of NFRCs to synthetic fiber-based composites is proved in [36] where the epoxy is used as a resin reinforced with jute fibers and glass fibers. The erosion wear tests were conducted according to ASTM G76-07 under the operating parameters presented in Table 5.

Table 5. Experimental conditions for the erosion test [36].

\begin{tabular}{cc}
\hline \multicolumn{2}{c}{ Operating Parameters } \\
\hline Erodent & Silica sand \\
Erodent size $(\mu \mathrm{m})$ & $200 \pm 50$ \\
Erodent shape & Angular \\
Hardness of silica particles $(\mathrm{HV})$ & $1420 \pm 50$ \\
Impingement angle $\left(\alpha^{\circ}\right)$ & $30,45,60,90$ \\
Impact velocity $(\mathrm{m} / \mathrm{s})$ & 48 \\
Erodent feed rate $(\mathrm{gm} / \mathrm{min})$ & $2 \pm 0.5$ \\
Test temperature $\left({ }^{\circ} \mathrm{C}\right)$ & 27 \\
Nozzle to sample distance $(\mathrm{mm})$ & 10 \\
\hline
\end{tabular}

Taking into account the impingement angle, the authors concluded the jute/epoxy composite exhibited better weight loss resistance than glass/epoxy when the impingement angle was $90^{\circ}$ and $30^{\circ}$ for a brittle and ductile erosion, respectively. They reported the jute composites to provide the best erosion resistance of all the composites.

Table 6 summarizes the relevant investigations on the tribological characteristics of the NFRCs found in the scientific literature. 
Table 6. Relevant tribological investigations of the NFRCs.

\begin{tabular}{|c|c|c|c|c|}
\hline Publication & Fiber & Matrix & Method & Aim \\
\hline $\begin{array}{l}\text { C.W. Chin, B.F. Yousif (2009). Potential of kenaf fibres as reinforcement for tribological } \\
\text { applications. Paper: Wear [30] }\end{array}$ & Kenaf & $\begin{array}{l}\text { Liquid epoxy } \\
\text { (DER 331) }\end{array}$ & $\begin{array}{l}\text { A block-on-disk (BOD) configuration was used to study surface specimens } \\
(10 \mathrm{~mm} \times 10 \mathrm{~mm} \times 20 \mathrm{~mm}) \text { against a stainless steel counterface. At applied } \\
\text { load }(30-100 \mathrm{~N}) \text {, sliding distance }(0-5 \mathrm{~mm}) \text {, at room temperature }\left(28^{\circ} \mathrm{C}\right) \\
\text { and at different sliding velocity }(1.1-3.9 \mathrm{~m} / \mathrm{s}) \text { the tests were conducted. }\end{array}$ & $\begin{array}{l}\text { Investigation on the wear and friction } \\
\text { performances of the epoxy at different } \\
\text { wt\% of kenaf fiber at different fiber } \\
\text { orientation. }\end{array}$ \\
\hline $\begin{array}{l}\text { Umar Nirmal, B.F. Yousif, Dirk Rilling, P.V. Brevern (2010). Effect of beteluut fibres } \\
\text { treatment and contact conditions on adhesive wear and frictional performance of polyester } \\
\text { composites. Paper: Wear [32] }\end{array}$ & Betelnut & Polyester & $\begin{array}{l}\text { At a sliding speed of } 2.8 \mathrm{~m} / \mathrm{s} \text { at a load of } 5-200 \mathrm{~N} \text {, using a block-on-disk } \\
\text { configuration, the tests were conducted under dry and wet conditions at a } \\
\text { sliding distance of } 0-6.72 \mathrm{~km} \text {. At a temperature of } 40^{\circ} \mathrm{C} \text { for } 24 \mathrm{~h} \text {, after the } \\
\text { test, all samples were dried in the oven. }\end{array}$ & $\begin{array}{l}\text { The wear and friction performances } \\
\text { under wet and dry contact conditions } \\
\text { controlled by fiber orientation. }\end{array}$ \\
\hline $\begin{array}{l}\text { B.F. Yousif, E.N.S.M. Tayeb (2007). The effect of oil palm fibers as reinforcement on } \\
\text { tribological performance of polyester composite. Paper: Surface Review and Letters [36] }\end{array}$ & Oil palm & Polyester & $\begin{array}{l}\text { In ambient conditions, friction-wear tests were conducted with different } \\
\text { experimental parameters. The sliding distances of } 0-5 \mathrm{~km} \text {, sliding speed of } \\
1.7,2.8, \text { and } 3.9 \mathrm{~m} / \mathrm{s} \text {, and applied loads of } 30,50,70, \text { and } 100 \mathrm{~N} \text { are set up. } \\
\text { Oil palm } \mathrm{m} \text { /polyester composite was tested against polished stainless steel } \\
\text { counterface using pin-on-disk configuration. }\end{array}$ & $\begin{array}{l}\text { Influence of oil palm fibers within the } \\
\text { polyester on friction and wear } \\
\text { characteristics in comparison with neat } \\
\text { polyester. }\end{array}$ \\
\hline $\begin{array}{l}\text { F.Z. Alshammari, K.H. Saleh, B.F. Yousif, A. Alajmi, A. Shalwan, J.G. Alotaibi (2018). } \\
\text { The Influence of Fibre Orientation on Tribological Performance ef Jute Fibre Reinforced Epoxy } \\
\text { Composites Considering Different Mat Orientations. Paper: Tribology in Industry [44] }\end{array}$ & Jute & Epoxy & $\begin{array}{l}\text { Considering three different fiber orientations with respect to sliding } \\
\text { direction, the tests were conducted at } 3 \mathrm{~m} / \mathrm{s} \text { sliding velocity with } 30 \mathrm{~N} \text { of } \\
\text { applied load using block-on-ring (BOR) configuration for a sliding period } \\
\text { of } 60 \text { min which is about } 10 \mathrm{~km} \text { sliding distance. }\end{array}$ & $\begin{array}{l}\text { Analysis of the fiber orientation influence } \\
\text { on frictionala and wear performances of } \\
\text { jute/epoxy composite. }\end{array}$ \\
\hline $\begin{array}{l}\text { Nor Amalina Nordin, Fauziah Md Yussof, Salmiah Kasolang, Zuraidah Salleh and } \\
\text { Mohamad Ali Ahmad (2013). Wear Rate of Natural Fibre: Long Kenaf Composite; The } \\
\text { Malaysian International Tribology Conference } 2013 \text { [56] }\end{array}$ & Kenaf & Epoxy and Polyester & $\begin{array}{l}\text { At room temperature, the wear tests were conducted at a constant sliding } \\
\text { speed of } 1.4 \mathrm{~m} / \mathrm{s} \text { under dry conditions. An abrasion resistance tester } \\
\text { (TR-600) is used with applied loads of } 5-30 \mathrm{~N} \text {. }\end{array}$ & $\begin{array}{l}\text { Study of the specific wear rate behavior } \\
\text { of kenaf/polyester and kenaf//poxy } \\
\text { composites. }\end{array}$ \\
\hline $\begin{array}{l}\text { Ashafi'e Mustafa, Mohd Fadzli Bin Abdollah, Fairuz Fazillah Shuhimi, Nurhidayah } \\
\text { Ismail, Hilmi Amiruddin, Noritsugu Umehara (2015). Selection and verification of kenaf } \\
\text { fibres as an an alternative friction material using Weighted Decision Matrix method. Paper: } \\
\text { Materials \& Design [66] }\end{array}$ & Kenaf, jute, ramie & - & Weighted decision matrix (WDM) approach. & $\begin{array}{l}\text { Verification of kenaf fiber as a suitable } \\
\text { filler of composite in the automotive } \\
\text { industry. }\end{array}$ \\
\hline $\begin{array}{l}\text { Vlastimil Matějka, Zhezhen Fu, Jana Kukutschová, Shicheng Qi, Shengling Jiang, Xiaoa } \\
\text { Zhang, Rongping Yun, Miroslav Vaculik, Marie Heliová, Yafei Lu (2013). Jute fibers and } \\
\text { poovderized hazelnut thells as satural fillers in non-asbestos organic non-metallic friction } \\
\text { composites. Paper: Materials \& Design [74] }\end{array}$ & $\begin{array}{l}\text { Jute fibers and } \\
\text { hazelnut shells }\end{array}$ & Phenolic resin & $\begin{array}{l}\text { Friction-wear chase test was performed based on SAEJ661 (Society of } \\
\text { Automotive Engineers standard procedure). }\end{array}$ & $\begin{array}{l}\text { Research on the non-asbestos organic } \\
\text { friction composites filled by jute fibers } \\
\text { and powdered hazelnut shells. }\end{array}$ \\
\hline $\begin{array}{l}\text { Petr Valášsek, Alessandro Ruggiero, Miroslav Müller (2017). Experimental description of } \\
\text { strenghth and tribological characteristic cof EFB oil palm fibresepoxy composites with } \\
\text { trechnologically undemanding preparation. Paper: Composites Part B: Engineering [75] }\end{array}$ & Oil palm & Epoxy & $\begin{array}{l}\text { Chemically treated and non-treated fibers are tested with two-body } \\
\text { abrasion tests using a rotating cylindrical drum. The drum was covered } \\
\text { with cloth of the P120 and Alzo3 grain size. The chemically treated fibers } \\
\text { were soaked into a } 6 \% \text { solution of NaOH. }\end{array}$ & $\begin{array}{l}\text { Study of the tribo-mechanical properties } \\
\text { of treated and non-treated oil palm fibers } \\
\text { with different experimental parameters. }\end{array}$ \\
\hline $\begin{array}{l}\text { Gupta, M K, Srivastava, R K (2016). Tribological and dynamic mechanical analysis of epoxy } \\
\text { based hybrid sisal/jute composite. Paper: Indian Journal of Engineering and Materials } \\
\text { Sciences [98] }\end{array}$ & Sisal and jute & Epoxy & $\begin{array}{l}\text { Based on the ASTM G99-95 standard, a wear test is performed. With a } \\
\text { normal load of } 10-30 \mathrm{~N} \text {, sliding speed of } 1-3 \mathrm{~m} / \mathrm{s} \text {, using pin-on-disk } \\
\text { configuration (ground hardened steel disk), with sliding distance } \\
1000-3000 \mathrm{~m} \text {, test has conducted. }\end{array}$ & $\begin{array}{l}\text { Tribo-mechanical analysis considering } \\
\text { alkali treatment of fibers. }\end{array}$ \\
\hline $\begin{array}{l}\text { Vijay Chaudhary, Pramendra Kumar Bajpai, Sachin Maheshwari (2018). An } \\
\text { Investigation on Wear and Dynamic Mechanical behavior of Jute/HemplFlax Reinforced } \\
\text { Composites and Its Hybrids for Tribological Applications. Paper: Fibers and Polymers [99] }\end{array}$ & Jute, hemp and flax & Epoxy & $\begin{array}{l}\text { With a Pin-On-Disk tribometer wear test is conducted. The test conditions } \\
\text { were set up on } 1-5 \mathrm{~m} / \mathrm{s} \text { sliding speed, } 10-50 \mathrm{~N} \text { applied load and } 1000-2000 \\
\mathrm{~m} \text { sliding distance. }\end{array}$ & $\begin{array}{l}\text { Investigation on friction and wear } \\
\text { improvement of natural fiber-reinforced } \\
\text { composites in comparison to neat epoxy } \\
\text { polymer. }\end{array}$ \\
\hline $\begin{array}{l}\text { A.M. Eleiche, G.M. Amin (1986). The effect of unidirectional cotton fibre reinforcement on the } \\
\text { friction and wear characteristics of polyester. Paper: Wear [100] }\end{array}$ & Cotton & Polyester & $\begin{array}{l}\text { At an ambient temperature of about } 22^{\circ} \mathrm{C} \text {, the tests were performing with } \\
\text { pin-on-disk configuration under rdry conditions. The specimens were } \\
\text { tested against stainless steel disk under a normal load of } 50 \mathrm{~N} \text {. Using the } \\
\text { Lancaster method, computed velocity below and above the } \\
\text { pressure-velocity limit of pure polyester, equivalent to } 10 \text { and } 32 \mathrm{~cm} \mathrm{~s}^{-1} \\
\text { sliding speed. }\end{array}$ & $\begin{array}{l}\text { Study of the wear rate and friction } \\
\text { coefficient of cotton/polyester composite } \\
\text { against stainless steel. }\end{array}$ \\
\hline $\begin{array}{l}\text { C.H. Chandra Rao, S. Madhusudan, G. Raghavendra, E. Venkateswara Rao (2012). } \\
\text { Investigation in to Wear behavior of coir Fiber Reinforced Epoxy Composites with the Taguchi } \\
\text { Method. Paper. International Journal of Engineering Research and Applications [101] }\end{array}$ & Coir & Epoxy & $\begin{array}{l}\text { With a different running speed, the two-body abrasion wear tests were } \\
\text { conducted using pin-on-disk configuration. The waterproof silicon carbide } \\
\text { abrasive papers of } 320 \text { grit were used against polished samples with } 32 \\
\mathrm{~mm} \text { length and } 10 \mathrm{~mm} \text { diameter. }\end{array}$ & $\begin{array}{l}\text { Study of the wear resistance of treated } \\
\text { and untreated coir dust/epoxy } \\
\text { composites. }\end{array}$ \\
\hline
\end{tabular}




\section{Conclusions}

To obtain suitable ecofriendly materials, in recent years, natural fiber-reinforced composites were considered as a valid alternative to classical synthetic fiber-based composites. To create them, many kinds of natural fibers should be used in different matrices, such as kenaf, jute, oil palm, coir, and many others plant fibers, animal fibers, or mineral fibers. Of course, using them in mechanical applications or in general in industry it is necessary to test them and to characterize their mechanical and tribological behavior. In particular, the tribological characterization of NFRCs represents a novel research field in which a relatively low number of papers are present in the literature. This manuscript intends, in the limitations of the lack in literature data, to give an overview of the scientific results on this topic, based on relevant and recent scientific literature, with the aim to give to the readers a framework of this scientific issues in which new insights should be detected. In particular, the authors focused on the influence of fiber orientation, fiber chemical treatments, and operative conditions (imposed loads and sliding velocities) on some NFRCs' friction and wear behavior.

Moreover, results are discussed regarding the chemical treatments used to improve the frictional and wear characteristics of the investigated materials allowing to conclude, in the limitation of the considered NFRCs, better wear performances when chemical fiber treatment is used.

In general, the addition of natural fibers to polymer matrices improve the wear performances of NFRCs in comparison with the wear properties of neat polymer materials. As a general conclusion of this overview it should be reported that, even if a set of standardized tribological testing procedures for such kind of materials should be desirable, for immediate comparison of the experimental results obtained in the different investigations, to date, on the basis of literature, the tribo-mechanical characteristics of natural fibers and their composites have shown that some kinds of natural fibers have the potential to replace synthetic materials in the realization of fiber-reinforced composite materials. Of course, further investigations are required to complete the characterization of NFRCs by taking into account the possible combinations of matrices/natural fibers and percentage/orientation of fibers in the matrix. In particular, the key research gap for future investigations in the framework of tribology should be highlighted in the following main directions:

- Definition of suitable friction and wear measurement protocols accounting for the orientation of fibers in the matrix with respect to the sliding motion, characteristic of each adopted tribological test;

- Investigations on the effects of fiber treatment, fiber orientation, and fiber volume fraction, at various loads and temperatures, on tribological properties of NFRCs; and

- Tribological characterization of novel combinations of green matrix/fiber type both in dry and lubricated conditions.

However, theoretical and numerical investigations on the contact phenomena in NFRCs accounting for multi-scale approaches for the complete understanding and modelling of wear phenomena are mandatory.

Author Contributions: All authors listed have made a substantial, direct, and intellectual contributions to the work, and approved it for publication. All authors have read and agreed to the published version of the manuscript.

Funding: This research received no external funding.

Conflicts of Interest: The authors declare no conflict of interest.

\section{References}

1. Torabinejad, V.; Aliofkhazraei, M.; Assareh, S.; Allahyarzadeh, M.H.; Sabour, A. Rouhaghdam. Electrodeposition of Ni-Fe alloys, composites, and nano coatings-A review. J. Alloy. Compd. 2017, 691, 841-859. [CrossRef]

2. Holmberg, K.; Erdemir, A. Influence of tribology on global energy consumption, costs and emissions. Friction 2017, 5, 263-284. [CrossRef] 
3. Holmberg, K.; Kivikytö-Reponen, P.; Härkisaari, P.; Valtonen, K.; Erdemir, A. Global energy consumption due to friction and wear in the mining industry. Tribol. Int. 2017, 115, 116-139. [CrossRef]

4. Bhushan, B. Introduction to Tribology, 2nd ed.; John Wiley \& Sons Ltd: Hoboken, NJ, USA, 2013; pp. 1-201.

5. Staab, G.H. Laminar Composites, 2nd ed.; Butterworth-Heinemann (Elsevier): Oxford, UK, 2015; p. 1.

6. Pachta, V.; Stefanidou, M.; Konopisi, S.; Papayianni, I. Technological evolution of historic structural mortars. J. Civ. Eng. Archit. 2014, 8, 846-854.

7. Thiroumalini, P.; Sekar, S.K. Review on herbs used as admixture in lime mortar used in ancient structures. Indian J. Appl. Res. 2013, 3, 295-298. [CrossRef]

8. Nägeli, C.; Camarasa, C.; Jakob, M.; Catenazzi, G.; Ostermeyer, Y. Synthetic building stocks as a way to assess the energy demand and greenhouse gas emissions of national building stocks. Energy Build. 2018, 173, 443-460. [CrossRef]

9. Dente, S.M.R.; Aoki-Suzuki, C.; Tanaka, D.; Hashimoto, S. Revealing the life cycle greenhouse gas emissions of materials: The Japanese case. Resourc. Conserv. Recycl. 2018, 133, 395-403. [CrossRef]

10. Shahinur, S.; Hasan, M. Natural fiber and synthetic fiber composites: Comparison of properties, performance, cost and environmental benefits. Ref. Modul. Mater. Sci. Mater. Eng. 2019. [CrossRef]

11. Sanal, I.; Verma, D. Construction Materials Reinforced with Natural Products. In Handbook of Ecomaterials; Martínez, L.M.T., Kharissova, O.V., Kharisov, B.I., Eds.; Springer: Basel, Switzerland, 2019; pp. 1-24.

12. Saxena, M.; Pappu, A.; Sharma, A.; Haque, R.; Wankhede, S. Composite Materials from Natural Resources: Recent Trends and Future Potentials. In Advances in Composite Materials—Analysis of Natural and ManMade Materials; Tesinova, P., Ed.; InTech: Rijeka, Croatia, 2011; pp. 121-163.

13. Satyanarayana, K.G.; Arizaga, G.G.C.; Wypych, F. Biodegradable composites based on lignocellulosic fibers-An overview. Prog. Polym. Sci. 2009, 34, 982-1021. [CrossRef]

14. Balla, V.K.; Kate, K.H.; Satyavolu, J.; Singh, P.; Tadimeti, J.G.D. Additive manufacturing of natural fiber reinforced polymer composites: Processing and prospects. Compos. Part B Eng. 2019, 174, 106956. [CrossRef]

15. Elanchezhian, C.; Ramnath, B.V.; Ramakrishnan, G.; Rajendrakumar, M.; Naveenkumar, V.; Saravanakumar, M.K. Review on mechanical properties of natural fiber composites. Mater. Today Proc. 2018, 5, 1785-1790. [CrossRef]

16. Ruggiero, A.; Valášek, P.; Müller, M. Exploitation of waste date seeds of Phoenix dactylifera in form of polymeric particle biocomposite: Investigation on adhesion, cohesion and wear. Compos. Part B Eng. 2016, 104, 9-16. [CrossRef]

17. Saheb, D.N.; Jog, J.P. Natural fiber polymer composites: A review. Adv. Polym. Technol. 1999, 18, 351-363. [CrossRef]

18. Popov, V.L. Qualitative Treatment of Contact Problems-Normal Contact without Adhesion. In Contact Mechanics and Friction, Physical Principles and Applications, 2nd ed.; Popov, V.L., Ed.; Springer: Berlin, Germany, 2017; pp. 9-23.

19. Popov, V.L.; Heß, M.; Willert, E. Handbook of Contact Mechanics, Exact Solutions of Axisymmetric Contact Problems, 1st ed.; Springer: Berlin, Germany, 2019; pp. 5-66.

20. D'Agostino, V. Fondamenti di Meccanica Applicata alle Macchine, 3rd ed.; Maggioli Editore: Rimini, Italy, 2013; pp. 124-138.

21. Rahnejat, H. An introduction to multi-physics multi-scale approach. In Tribology and Dynamics of Engine and Powertrain, Fundamentals, Applications and Future Trends, 1st ed.; Rahnejat, H., Ed.; Woodhead Publishing: Sawston, UK, 2010; pp. 3-38.

22. Rahnejat, H.; Johns-Rahnejat, P.M. Mechanics of contacting surfaces. In Encyclopedia of Automotive Engineering; John Wiley \& Sons Ltd: Hoboken, NJ, USA, 2014; pp. 1-9.

23. Boucly, V.; Nélias, D.; Liu, S.; Wang, Q.J.; Keer, L.M. Contact analyses for bodies with frictional heating and plastic behavior. J. Tribol. 2005, 127, 355-364. [CrossRef]

24. Yevtushenko, A.A.; Kuciej, M. One-dimensional thermal problem of friction during braking: The history of development and actual state. Int. J. Heat Mass Transf. 2012, 55, 4148-4153. [CrossRef]

25. Liu, C.R.; Guo, Y.B. Finite element analysis of the effect of sequential cuts and tool-chip friction on residual stresses in a machined layer. Int. J. Mech. Sci. 2000, 42, 1069-1086. [CrossRef]

26. Bassani, R.; Levita, G.; Meozzi, M.; Palla, G. Friction and wear of epoxy resin on inox steel: Remarks on the influence of velocity, load and induced thermal state. Wear 2001, 247, 125-132. [CrossRef] 
27. Páczelt, I.; Mróz, Z. Variational approach to the analysis of steady-state thermo-elastic wear regimes. Int. J. Numer. Methods Eng. 2009, 81, 728-760. [CrossRef]

28. Lim, S.C.; Ashby, M.F. Overview No. 55 Wear-Mechanism maps. Acta Metall. 1987, 35, 1-24. [CrossRef]

29. Amiri, M.; Khonsari, M.M. On the thermodynamics of friction and wear-A review. Entropy 2010, 12, 1021-1049. [CrossRef]

30. Chin, C.W.; Yousif, B.F. Potential of kenaf fibres as reinforcement for tribological applications. Wear 2009, 267, 1550-1557. [CrossRef]

31. Yallew, T.B.; Kumar, P.; Singh, I. Sliding wear properties of jute fabric reinforced polypropylene composites. Procedia Eng. 2014, 97, 402-411. [CrossRef]

32. Nirmal, U.; Yousif, B.F.; Rilling, D.; Brevern, P.V. Effect of betelnut fibres treatment and contact conditions on adhesive wear and frictional performance of polyester composites. Wear 2010, 268, 1354-1370. [CrossRef]

33. Goriparthi, B.K.; Suman, K.N.S.; Rao, N.M. Effect of fiber surface treatments on mechanical and abrasive wear performance of polylactide/jute composites. Compos. Part A Appl. Sci. Manuf. 2012, 43, 1800-1808. [CrossRef]

34. Raghavendra, G.; Ojha, S.; Acharya, S.K.; Pal, S.K. Jute fiber reinforced epoxy composites and comparison with the glass and neat epoxy composites. J. Compos. Mater. 2013, 48, 2537-2547. [CrossRef]

35. Shuhimi, F.F.; Abdollah, M.F.B.; Kalam, M.A.; Hassan, M.; Mustafa, A.; Amiruddin, H. Tribological characteristics comparison for oil palm fibre/epoxy and kenaf fibre/epoxy composites under dry sliding conditions. Tribol. Int. 2016, 101, 247-254. [CrossRef]

36. Yousif, B.F.; Tayeb, E.N.S.M. The effect of oil palm fibers as reinforcement on tribological performance of polyester composite. Surf. Rev. Lett. 2007, 14, 1095-1102. [CrossRef]

37. Liang, Y.N.; Li, S.Z.; Zhang, R.H.; Li, S. Effect of fiber orientation on a graphite fiber composite in single pendulum scratching. Wear 1996, 198, 122-128. [CrossRef]

38. Xess, P.A. Erosion Wear Behaviour of Bamboo Fiber Based Hybrid Composites. Master's Thesis, Department of Mechanical Engineering, National Institute of Technology, Rourkela, India, May 2012.

39. Alves, C.; Ferrão, P.M.C.; Silva, A.J.; Reis, L.G.; Freitas, M.; Rodrigues, L.B.; Alves, D.E. Ecodesign of automotive components making use of natural jute fiber composites. J. Clean. Prod. 2010, 18, 313-327. [CrossRef]

40. Rodríguez-Tembleque, L.; Aliabadi, M.H. Friction and wear modelling in fiber-reinforced composites. Comput. Model. Eng. Sci. 2014, 102, 183-210.

41. Din, I.U.; Panier, S.; Hao, P.; Franz, G.; Bijwe, J.; Hui, L. Finite element modeling of indentation and adhesive wear in sliding of carbon fiber reinforced thermoplastic polymer against metallic counterpart. Tribol. Int. 2019, 135, 200-212. [CrossRef]

42. Gupta, M.; Wang, K.K. Fiber orientation and mechanical properties of short-fiber-reinforced injection-molded composites: Simulated and experimental results. Polym. Compos. 1993, 14, 367-382. [CrossRef]

43. Nak-Ho, S.; Suh, N.P. Effect of fiber orientation on friction and wear of fiber reinforced polymeric composites. Wear 1979, 53, 129-141.

44. Alshammari, F.Z.; Saleh, K.H.; Yousif, B.F.; Alajmi, A.; Shalwan, A.; Alotaibi, J.G. the influence of fibre orientation on tribological performance of jute fibre reinforced epoxy composites considering different mat orientations. Tribol. Ind. 2018, 40, 335-348. [CrossRef]

45. El-Tayeb, N.S.M. A study on the potential of sugarcane fibers/polyester composite for tribological applications. Wear 2008, 265, 223-235. [CrossRef]

46. Stachowiak, G.W.; Batchelor, A.W.; Stachowiak, G.B. Experimental Methods in Tribology, 1st ed.; Elsevier: Oxford, UK, 2004; pp. 25-78.

47. Liguori, C.; Ruggiero, A.; Russo, D.; Sommella, P. A statistical approach for improving the accuracy of dry friction coefficient measurement. IEEE Trans. Instrum. Meas. 2019, 68, 1412-1423. [CrossRef]

48. Mang, T.; Dresel, W. Lubricants and Lubrication, 2nd ed.; Wiley-VCH GmbH: Weinheim, Germany, 2007; pp. 737-739.

49. Lanza, A.; Ruggiero, A.; Sbordone, L. Tribology and dentistry: A commentary. Lubricants 2019, 7, 52. [CrossRef]

50. Khalil, H.P.S.A.; Alwani, M.S.; Ridzuan, R.; Kamarudin, H.; Khairul, A. Chemical composition, morphological characteristics, and cell wall structure of Malaysian oil palm fibres. Polym. Plast. Technol. Eng. 2008, 47, 273-280. [CrossRef] 
51. Yousif, B.F.; El-Tayeb, N.S.M. Adhesive wear performance of T-OPRP and UT-OPRP composites. Tribol. Lett. 2008, 32, 199-208. [CrossRef]

52. Ayrilmis, N.; Jarusombuti, S.; Fueangvivat, V.; Bauchongkol, P.; White, R.H. Coir Fiber Reinforced Polypropylene composite panel for automotive interior applications. Fibers Polym. 2011, 12, 919-926. [CrossRef]

53. Shireesha, Y.; Nandipati, G. State of art review on natural fibers. Mater. Today Proc. 2019, 18, 15-24. [CrossRef]

54. Akil, H.M.; Omar, M.F.; Mazuki, A.A.M.; Safiee, S.; Ishak, Z.A.M.; Bakar, A.A. Kenaf fiber reinforced composites: A review. Mater. Des. 2011, 32, 4107-4121. [CrossRef]

55. Zampaloni, M.; Pourboghrat, F.; Yankovich, S.A.; Rodgers, B.N.; Moore, J.; Drzal, L.T.; Mohanty, A.K.; Misra, M. Kenaf natural fiber reinforced polypropylene composites: A discussion on manufacturing problems and solutions. Compos. Part A Appl. Sci. Manuf. 2007, 38, 1569-1580. [CrossRef]

56. Nordin, N.A.; Yussof, F.M.; Kasolang, S.; Salleh, Z.; Ahmad, M.A. Wear rate of natural fibre: Long kenaf composite. Procedia Eng. 2013, 68, 145-151. [CrossRef]

57. Yousif, B.F.; Chin, C.W. Epoxy composite based on kenaf fibers for tribological applications under wet contact conditions. Surf. Rev. Lett. 2012, 19, 1250050-1-1250050-6. [CrossRef]

58. Archard, J.F. Contact and rubbing of flat surfaces. J. Appl. Phys. 1953, 24, 981-988. [CrossRef]

59. Edeerozey, A.M.M.; Akil, H.M.; Azhar, A.B.; Ariffin, M.I.Z. Chemical modification of kenaf fibers. Mater. Lett. 2007, 61, 2023-2025. [CrossRef]

60. Serizawa, S.; Inoue, K.; Iji, M. Kenaf-fiber-reinforced poly (lactic acid) used for electronic products. J. Appl. Polym. Sci. 2006, 100, 618-624. [CrossRef]

61. Ochi, S. Mechanical properties of kenaf fibers and kenaf/PLA composites. Mech. Mater. 2008, 40, 446-452. [CrossRef]

62. Wang, J.; Ramaswamy, G.N. One-step processing and bleaching of mechanically separated kenaf fibers: Effects on physical and chemical properties. Text. Res. J. 2003, 73, 339-344. [CrossRef]

63. Saba, N.; Paridah, M.T.; Jawaid, M. Mechanical properties of kenaf fibre reinforced polymer composite: A review. Constr. Build. Mater. 2015, 76, 87-96. [CrossRef]

64. Komuraiah, A.; Kumar, N.S.; Prasad, B.D. Chemical composition of natural fibers and its influence on their mechanical properties. Mech. Compos. Mater. 2014, 50, 359-376. [CrossRef]

65. Khalil, H.P.S.A.; Jawaid, M.; Hassan, A.; Paridah, M.T.; Zaidon, A. Oil palm biomass fibres and recent advancement in oil palm biomass fibres based hybrid biocomposites. In Composites and Their Applications; Hu, N., Ed.; InTech: Rijeka, Croatia, 2012; pp. 209-242.

66. Mustafa, A.; Abdollah, M.F.B.; Shuhimi, F.F.; Ismail, N.; Amiruddin, H.; Umehara, N. Selection and verification of kenaf fibres as an alternative friction material using Weighted Decision Matrix method. Mater. Des. 2015, 67, 577-582. [CrossRef]

67. Chin, C.W.; Yousif, F. Influence of particle size, applied load, and fibre orientation on 3B-A wear and frictional behaviour of epoxy composite based on kenaf fibres. Proc. Inst. Mech. Eng. Part J J. Eng. Tribol. 2010, 224, 481-489. [CrossRef]

68. Narish, S.; Yousif, B.F.; Rilling, D. Adhesive wear of thermoplastic composite based on kenaf fibres. Proc. Inst. Mech. Eng. Part J J. Eng. Tribol. 2011, 225, 101-109. [CrossRef]

69. Krishna, K.V.; Kanny, K. The effect of treatment on kenaf fiber using green approach and their reinforced epoxy composites. Compos. Part B Eng. 2016, 104, 111-117. [CrossRef]

70. Acha, B.A.; Marcovich, N.E.; Reboredo, M.M. Physical and mechanical characterization of jute fabric composites. J. Appl. Polym. Sci. 2005, 98, 639-650. [CrossRef]

71. El-Sayed, A.A.; El-Sherbiny, M.G.; Abo-El-Ezz, A.S.; Aggag, G.A. Friction and wear properties of polymeric composite materials for bearing applications. Wear 1995, 184, 45-53. [CrossRef]

72. Chand, N.; Dwivedi, U.K. Effect of coupling agent on abrasive wear behaviour of chopped jute fibre-reinforced polypropylene composites. Wear 2006, 261, 1057-1063. [CrossRef]

73. Dwivedi, U.K.; Chand, N. Influence of fibre orientation on friction and sliding wear behaviour of jute fibre reinforced polyester composite. Appl. Compos. Mater. 2009, 16, 93-100. [CrossRef]

74. Matějka, V.; Fu, Z.; Kukutschová, J.; Qi, S.; Jiang, S.; Zhang, X.; Yun, R.; Vaculík, M.; Heliová, M.; Lu, Y. Jute fibers and powderized hazelnut shells as natural fillers in non-asbestos organic non-metallic friction composites. Mater. Des. 2013, 51, 847-853. [CrossRef] 
75. Valášek, P.; Ruggiero, A.; Müller, M. Experimental description of strength and tribological characteristic of EFB oil palm fibres/epoxy composites with technologically undemanding preparation. Compos. Part B Eng. 2017, 122, 79-88. [CrossRef]

76. Shinoj, S.; Visvanathan, R.; Panigrahi, S.; Kochubabu, M. Oil palm fiber (OPF) and its composites: A review. Ind. Crops Prod. 2011, 33, 7-22. [CrossRef]

77. Wirjosentono, B.; Guritno, P.; Ismail, H. Oil palm empty fruit bunch filled polypropylene composites. Int. J. Polym. Mater. 2004, 53, 295-306. [CrossRef]

78. Rozman, H.D.; Lai, C.Y.; Ismail, H.; Ishak, Z.A.M. The effect of coupling agents on the mechanical and physical properties of oil palm empty fruit bunch-polypropylene composites. Polym. Int. 2000, 49, 1273-1278. [CrossRef]

79. Karina, M.; Onggo, H.; Abdullah, A.H.D.; Syampurwadi, A. Effect of oil palm empty fruit bunch fiber on the physical and mechanical properties of fiber glass reinforced polyester resin. J. Biol. Sci. 2008, 8, 101-106.

80. Badri, K.H.; Othman, Z.B.; Razali, I.M. Mechanical properties of poyurethane composites from oil palm resources. Iran. Polym. J. 2005, 14, 441-448.

81. Yousif, B.F.; El-Tayeb, N.S.M. High-stress three-body abrasive wear of treated and untreated oil palm fibre-reinforced polyester composites. Proc. Inst. Mech. Eng. Part J J. Eng. Tribol. 2008, 222, 637-646. [CrossRef]

82. Haque, M.M.; Hasan, M.; Islam, M.S.; Ali, M.E. Physico-mechanical properties of chemically treated palm and coir fiber reinforced polypropylene composites. Bioresour. Technol. 2009, 100, 4903-4906. [CrossRef]

83. Yan, L.; Su, S.; Chouw, N. Microstructure, flexural properties and durability of coir fibre reinforced concrete beams externally strengthened with flax FRP composites. Compos. Part B Eng. 2015, 80, 343-354. [CrossRef]

84. Adeniyi, A.G.; Onifade, D.V.; Ighalo, J.O.; Adeoye, A.S. A review of coir fiber reinforced polymer composites. Compos. Part B Eng. 2019, 176, 107305. [CrossRef]

85. Siakeng, R.; Jawaid, M.; Ariffin, H.; Salit, M.S. Effects of surface treatments on tensile, thermal and fibre-matrix bond strength of coir and pineapple leaf fibres with poly lactic acid. J. Bionic Eng. 2018, 15, 1035-1046. [CrossRef]

86. Valášek, P.; D'Amato, R.; Müller, M.; Ruggiero, A. Mechanical properties and abrasive wear of white/brown coir epoxy composites. Compos. Part B Eng. 2018, 146, 88-97. [CrossRef]

87. D, V.K.; N, M.; Bongale, A.K. Fabrication and tribological investigation of Coconut coir/Banana fiber/Glass fiber reinforced hybrid polymer matrix composites-A Taguchi's approach. Mater. Res. Express 2019, 6, 105345

88. Yousif, B.F. Frictional and wear performance of polyester composites based on coir fibres. Proc. Inst. Mech. Eng. Part J J. Eng. Tribol. 2009, 223, 51-59. [CrossRef]

89. Ibrahem, R.A. Friction and wear behaviour of fibre/particles reinforced polyester composites. Int. J. Adv. Mater. Res. 2016, 2, 22-26.

90. Khan, A.; Ahmad, M.A.; Joshi, S.; Al Said, S.A.F. Abrasive wear behavior of chemically treated coir fibre filled epoxy polymer composites. Am. J. Mech. Eng. Autom. 2014, 1, 1-5.

91. Yousif, B.F.; El-Tayeb, N.S.M. Mechanical and wear properties of oil palm and glass fibres reinforced polyester composites. Int. J. Precis. Technol. 2009, 1, 213-222. [CrossRef]

92. Samad, A.; Sinha, S.K. Mechanical, thermal and tribological characterization of a UHMWPE film reinforced with carbon nanotubes coated on steel. Tribol. Int. 2011, 44, 1932-1941. [CrossRef]

93. Mohammed, A.S.; Ali, A.B.; Nesar, M. Evaluation of tribological properties of organo-clay reinforced UHMWPE nanocomposites. J. Tribol. 2017, 139, 012001-1-012001-6. [CrossRef]

94. Ali, A.B.; Mohammed, A.S.; Nesar, M. UHMWPE hybrid nanocomposites for improved tribological performance under dry and water lubricated sliding conditions. Tribol. Lett. 2017, 65, 102. [CrossRef]

95. Aliyu, I.K.; Mohammed, A.S.; Al-Qutub, A. Tribological performance of ultra high molecular weight polyethylene nanocomposites reinforced with graphene nanoplatelets. Polym. Compos. 2018, 40, E1301-E1311. [CrossRef]

96. Hashmi, S.A.R.; Dwivedi, U.K.; Chand, N. Graphite modified cotton fibre reinforced polyester composites under sliding wear conditions. Wear 2007, 262, 1426-1432. [CrossRef]

97. Yousif, B.F.; El-Tayeb, N.S.M. Tribological evaluations of polyester composites considering three orientations of CSM glass fibres using BOR machine. Appl. Compos. Mater. 2007, 14, 105-116. [CrossRef] 
98. Gupta, M.K.; Srivastava, R.K. Tribological and dynamic mechanical analysis of epoxy based hybrid sisal/jute composite. Indian J. Eng. Mater. Sci. 2016, 23, 37-44.

99. Chaudhary, V.; Bajpai, P.K.; Maheshwari, S. An investigation on wear and dynamic mechanical behavior of jute/hemp/flax reinforced composites and its hybrids for tribological applications. Fibers Polym. 2018, 19, 403-415. [CrossRef]

100. Eleiche, A.M.; Amin, G.M. The effect of unidirectional cotton fibre reinforcement on the friction and wear characteristics of polyester. Wear 1986, 112, 67-78. [CrossRef]

101. Rao, C.H.C.; Madhusudan, S.; Raghavendra, G.; Rao, E.V. Investigation in to wear behavior of coir fiber reinforced epoxy composites with the taguchi method. Int. J. Eng. Res. Appl. 2012, 2, 371-374.

(C) 2020 by the authors. Licensee MDPI, Basel, Switzerland. This article is an open access article distributed under the terms and conditions of the Creative Commons Attribution (CC BY) license (http://creativecommons.org/licenses/by/4.0/). 